\title{
Regulation of Isocitrate Dehydrogenase Activity in Escherichia coli on Adaptation to Acetate
}

\author{
By W. H. HOLMS AND P. M. BENNETT \\ Department of Biochemistry, \\ University of Glasgow, Glasgow W. 2
}

(Accepted for publication 20 November 1970)

\begin{abstract}
SUMMARY
Escherichia coli grown aerobically in glucose + salts medium excretes acetate. On glucose exhaustion, the cells synthesize the enzymes of the glyoxylate bypass which permits growth on acetate as sole source of carbon and energy. Concurrently, the activity of isocitrate dehydrogenase falls to $20 \%$ and, when the acetate is exhausted, is restored to $75 \%$ of the original level. Similar results are obtained after growth on substrates (e.g. glycerol) which do not promote excretion of acetate, provided acetate is added to the medium at the end of growth. This control of isocitrate dehydrogenase activity is apparently a mechanism which restricts the flow of carbon round the tricarboxylic acid cycle and favours operation of the glyoxylate bypass.
\end{abstract}

\section{INTRODUCTION}

Escherichia coli excretes acetate when grown aerobically in simple, defined media containing glucose as sole source of carbon and energy (Britten, 1954). Little or no work has been done on the subsequent utilization of the excreted acetate. Escherichia coli cannot use acetate as sole source of carbon and energy until it synthesizes the enzymes of the glyoxylate bypass (Ashworth \& Kornberg, 1964). This anaplerotic pathway is repressed during growth on glucose and it follows that, on exhaustion of glucose, cells are unable to utilize acetate for synthetic purposes. They may, however, oxidize acetate by operation of the tricarboxylic acid cycle. When the glyoxylate bypass is operating it shares with the tricarboxylic acid cycle the available supply of carbon compounds derived from acetate. In particular, isocitrate lyase and isocitrate dehydrogenase compete for the same substrate and such a system might be susceptible to control.

We have therefore determined the activity of isocitrate dehydrogenase in Escherichia coli during and after its growth on limited glucose, and, for comparison, we have concurrently measured the activities of two other tricarboxylic acid cycle enzymes (2-oxoglutarate and malate dehydrogenases). As a control we have performed similar experiments with $E$. coli grown on a growth-limiting concentration of glycerol which is known not to provoke acetate accumulation and which Gray, Wimpenny \& Mossman (1960) had shown to give levels of isocitrate dehydrogenase not too dissimilar from those obtained on glucose.

Parts of this work have already been reported in a preliminary communication (Bennett \& Holms, 1969). 


\section{METHODS}

Organism. The organism used throughout this work was Escherichia coli ML 308 (ATCC I5224). Owing to a mutation in the gene coding for the repressor of the lactose operon $\left(i^{-} z^{+} y^{+} a^{+}\right)$, the organism synthesizes the enzymes of this operon constitutively. In other respects the strain is regarded as wild-type.

Media. Cultures were grown in a defined medium, consisting of a simple salts solution containing $40 \mathrm{mM}-\mathrm{KH}_{2} \mathrm{PO}_{4}$ (adjusted to $\mathrm{pH} 7 \cdot \mathrm{I}$ with $\mathrm{NaOH}$ ), IO $\mathrm{mM}-\left(\mathrm{NH}_{4}\right)_{2} \mathrm{SO}_{4}$, $2 \mathrm{mM}^{-} \mathrm{MgSO}_{4} \cdot 7 \mathrm{H}_{2} \mathrm{O}$, Io $\mu \mathrm{M}-\mathrm{FeSO}_{4} \cdot 7 \mathrm{H}_{2} \mathrm{O}$ (adjusted to $\mathrm{pH} 2 \cdot 0$ with $\mathrm{HCl}$ ), supplemented with glucose ( $2 \mathrm{mM})$ or glycerol $(4 \mathrm{mM})$ or as indicated in the text. Each component of the defined medium was autoclaved as a separate solution and the complete growth medium was constituted shortly before inoculation. The $\mathrm{pH}$ of the complete medium was $7 \cdot 1$. Batch cultures $\left(800 \mathrm{ml}\right.$.) were grown aerobically at $37^{\circ}$ as described by Harvey, Fewson \& Holms (1968).

Preparation of inocula. $100 \mathrm{ml}$. volumes of defined medium, in $500 \mathrm{ml}$. conical flasks, were inoculated with $0.1 \mathrm{ml}$. of a nutrient broth culture (stored at $4^{\circ}$ ) and incubated at $37^{\circ}$ on a Mark I a Orbital shaker (L. H. Engineering Co. Ltd, Bells Hill, Stoke Poges, Buckinghamshire) for $15 \mathrm{~h}$. Two serial subcultures in $100 \mathrm{ml}$. homologous medium were prepared using a $\mathrm{I} \%$ inoculum, and $7 \mathrm{~h}$. incubation. A third subculture was grown on the day prior to use and was stored at $4^{\circ}$ for $18 \mathrm{~h}$.; $10 \mathrm{ml}$. of this culture was used as the inoculum for $800 \mathrm{ml}$. of homologous growth medium.

Growth. Growth was determined turbidimetrically at $420 \mathrm{~nm}$., using quartz cuvettes (light path, I cm.), in a Unicam SP 800 spectrophotometer (Unicam Instruments Ltd, York Street, Cambridge) fitted with a desk type Servoscribe potentiometric recorder (Smiths Industries Ltd, Wembley, Middlesex). The extinction of the culture at $420 \mathrm{~nm}$. was directly proportional to total bacterial protein throughout growth, and a turbidity of $\mathrm{I} \cdot 0$ corresponded to $127 \mu \mathrm{g}$. bacterial protein and $196 \mu \mathrm{g}$. dry wt bacteria/ml. culture.

Enzyme extraction. For isocitrate dehydrogenase and isocitrate lyase determinations, $2 \mathrm{ml}$. of a growing culture were added to $2 \mathrm{ml}$. ice-cold $0.3 \mathrm{M}-\mathrm{NaCl}$ containing bovine plasma albumin (Io $\mathrm{mg} . / \mathrm{ml}$.). Three $\mathrm{ml}$. of the diluted culture were subjected to $75 \mathrm{sec}$. continuous ultrasonication, at $2.8 \mathrm{~A}$, using a soniprobe, type Ir $30 \mathrm{~A}$ (Dawe Instruments Ltd, Acton, London W. 3.) fitted with a probe of $\frac{1}{2}$ in. diameter. The cell suspension in a Trident container (Johnsen \& Jorgensen Ltd, London) was held in a brass holder screwed onto the horn of the soniprobe. The whole assembly was kept in an ice-water slurry and the brass holder effectively dissipated heat generated during the sonication. When 2-oxoglutarate dehydrogenase and malate dehydrogenase activities were determined, $3 \mathrm{ml}$. volumes of a buffered resuspension of harvested cells (see legend to Fig. 2) were subjected to continuous sonication, at I.8 A, for $60 \mathrm{sec}$. The extracts were used directly for all enzyme assays.

Enzyme assay. All enzyme assays were performed in $3 \mathrm{ml}$. total volume, in quartz cuvettes (light path, $1 \mathrm{~cm}$.), at $27^{\circ}$. Enzyme reactions were continuously followed in a Unicam SP 800 spectrophotometer fitted to a desk type Servoscribe recorder. Isocitrate dehydrogenase was determined in a reaction mixture containing $\mathrm{D}, \mathrm{L}$-isocitrate $\left(\mathrm{Na}_{3}\right.$ salt) (I mM), $\mathrm{MnCl}_{2} .4 \mathrm{H}_{2} \mathrm{O}(0.2 \mathrm{mM}), \mathrm{NADP}\left(\mathrm{Na}_{2}\right.$ salt) $(0.8 \mathrm{mM})$ in $32.5 \mathrm{~mm}$ 2-amino-2-hydroxymethylpropane-r,3-diol (tris) $\mathrm{pH} 7 \cdot 5$. The reaction was initiated by the addition of NADP, and was followed spectrophotometrically at $340 \mathrm{~nm}$. 
Malate dehydrogenase was assayed, using a modification of the procedure described by Mehler, Kornberg, Grisolia \& Ochoa (1948), in a reaction mixture containing, NADH $\left(\mathrm{Na}_{2}\right.$ salt) $(0.15 \mathrm{~mm})$, oxaloacetic acid $(0.2 \mathrm{mM})$ in $25 \mathrm{mM}$-glycylglycine buffer, $\mathrm{pH} 9.0$. The reaction was initiated by the addition of oxaloacetic acid and was followed at $340 \mathrm{~nm}$. 2-Oxoglutarate dehydrogenase was assayed using a modification of the method of Mukherjee, Matthews, Horney \& Reed (1965). The reaction mixture contained L-cysteine. $\mathrm{HCl}(3.3 \mathrm{mM})$, coenzyme A (0.33 mM), thiamine pyrophosphate $(0.33 \mathrm{mM}), \mathrm{KCN}(5 \mathrm{mM}), \mathrm{NAD}(\mathrm{I} \cdot \mathrm{I} 7 \mathrm{mM}), 2$-oxoglutarate (adjusted to $\mathrm{pH} 7.0$ with $\mathrm{NaOH})(6.7 \mathrm{~mm})$ in $0.17 \mathrm{M}$-tris buffer, $\mathrm{pH} 7.5$. The reaction was started by the addition of NAD quickly followed by 2-oxoglutarate and was followed at $340 \mathrm{~nm}$. The KCN solution was prepared at $30 \mathrm{~mm}$ and brought to $\mathrm{pH} 7 \cdot 5$ with $\mathrm{N}-\mathrm{HCl}$.

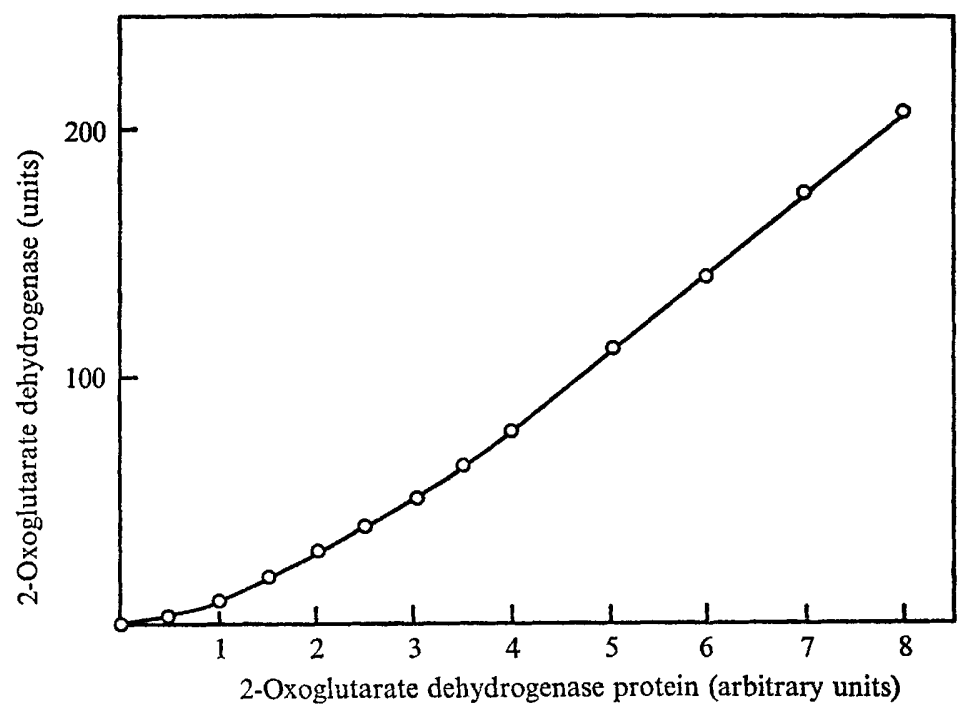

Fig. I. Relation between 2-oxoglutarate dehydrogenase activity and enzyme protein.

Isocitrate lyase was assayed using a modification of the method of Dixon \& Kornberg (I959). Enzyme activity was determined in a reaction mixture of $\mathrm{MgSO}_{4}(5 \mathrm{~mm})$, phenylhydrazine; $\mathrm{HCl}(3.3 \mathrm{mM})$, L-cysteine- $\mathrm{HCl}(2 \mathrm{mM})$, isocitric acid lactone $(6.7 \mathrm{mM})$ in $66.7 \mathrm{mM} \mathrm{KH}_{2} \mathrm{PO}_{4}, \mathrm{pH} 6 \cdot 8$. No special steps were taken to hydrolyse isocitric acid lactone, which was added to initiate the reaction, then followed at $324 \mathrm{~nm}$.

Isocitrate dehydrogenase and isocitrate lyase gave linear reaction rates for at least the first $3 \mathrm{~min}$. of the reaction, while malate dehydrogenase and 2-oxoglutarate dehydrogenase reaction rates were linear for $\mathrm{I}$ to $2 \mathrm{~min}$.

One enzyme unit is defined as that amount of enzyme which reduces I nmole of NAD or NADP, or oxidizes I nmole of NADH or forms I nmole of glyoxylic acid/ min. at $27^{\circ}$. The extinction coefficient of NADH or NADPH was assumed to be $6.22 \times 10^{6}$, and that of glyoxylic acid phenylhydrazone $1 \cdot 7 \times 10^{4}$ (Dixon \& Kornberg, 1959).

Enzyme activities were directly proportional to enzyme protein except for 2-oxoglutarate dehydrogenase (Fig. I), when activities were extrapolated onto the linear 
portion of the curve, and relative activities calculated. Specific activities of all enzymes are expressed as units of enzyme/extinction unit of culture at $420 \mathrm{~nm}$.

Acetate and glucose estimations. Acetate was estimated enzymically as described by the Boehringer Co. Ltd (information leaflet on acetate kinase). Two $\mathrm{ml}$. of the following reaction mixture was pipetted into a $3 \times \frac{1}{2}$ in. test tube: $188 \mathrm{ml}$. triethanolamine- $\mathrm{HCl}$, pH 7.4 (0.I M), $20 \mathrm{ml}$. ATP (Na salt) $(50 \mathrm{mg} . / \mathrm{ml}$ ), 10 $\mathrm{ml}$. phosphoenolpyruvate (K salt) (I5 mg. $/ \mathrm{ml}$.), $5 \mathrm{ml}$. NADH ( $\mathrm{Na}_{2}$ salt) (IO mg. $/ \mathrm{ml}$.), IO ml. $\mathrm{MgCl}_{2} \cdot 6 \mathrm{H}_{2} \mathrm{O}$ (0.2 M) $2 \mathrm{ml}$. pyruvate kinase $(2 \mathrm{mg} . / \mathrm{ml}$.), $2 \mathrm{ml}$. lactate dehydrogenase $(5 \mathrm{mg} . / \mathrm{ml}),. 2 \mathrm{ml}$. myokinase ( $2 \mathrm{mg}$. $/ \mathrm{ml}$.). A I $\mathrm{ml}$. sample containing acetate was added and the reaction was initiated by adding $40 \mu \mathrm{l}$. acetate kinase (I mg./ml.), delivered from an Eppendorf Marburgh mikroliterpipette (Netheler \& Hinz GMBH, Hamburg, Germany). Acetate concentration, within the range 0 to 400 nmoles/assay, was directly proportional to the decrease in extinction at $340 \mathrm{~nm}$. after $90 \mathrm{~min}$. at $27^{\circ}$. A standard curve was constructed with each set of assays performed.

Glucose was assayed according to the method of Slein (1963). The assay was performed in $3 \times \frac{1}{2}$ in. test tubes, in $3 \mathrm{ml}$. total volume, composed of $\mathrm{I} \mathrm{ml}$. glucose sample, I ml. tris buffer, $\mathrm{pH} 8 \cdot 0(0 . \mathrm{I} \mathrm{M}), 0.4 \mathrm{ml} . \mathrm{MgCl}_{2} .6 \mathrm{H}_{2} \mathrm{O}(50 \mathrm{mM}), 0 . \mathrm{I} \mathrm{ml}$. bovine

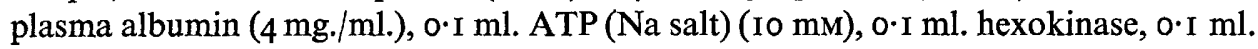
glucose 6-phosphate dehydrogenase, $0.2 \mathrm{ml}$. NADP ( $5 \mathrm{mM}$ ). Glucose concentration, within the range $O$ to 400 nmoles/assay, was directly proportional to the extent of reduction of NADP occurring over $30 \mathrm{~min}$. at $27^{\circ}$. A standard curve was constructed with each set of assays performed. Hexokinase (Sigma, type C-130, I30 units/mg.) was diluted $\mathrm{I}$ in 100 with a solution of bovine plasma albumin (100 $\mu \mathrm{g} . / \mathrm{ml}$.) before use. Glucose 6-phosphate dehydrogenase (Sigma, type X, 300 to 330 units/mg, now unobtainable) was diluted $I$ in 25 with glass distilled water before use.

Acetate and glucose assays were read at $340 \mathrm{~nm}$. in quartz cuvettes (light path, $\mathrm{I} \mathrm{cm}$.) in a Unicam SP 800 spectrophotometer, fitted to a desk type Servoscribe recorder.

Preparation of acetate and glucose samples. Samples for both acetate and glucose estimations were prepared by pipetting $4 \mathrm{ml}$. of growing culture onto $2 \mathrm{ml}$. of frozen tris buffer, $\mathrm{pH} 8.5(0 . \mathrm{IM})$, containing $\mathrm{MgCl}_{2}(\mathrm{O} . \mathrm{I} \mathrm{M})$ in a $6 \times 5 / 8 \mathrm{in}$. test tube and agitating the tube until the pellet of frozen buffer completely melted. Bacterial cells and precipitated magnesium phosphate were removed by centrifugation and the supernatant fluid was frozen and stored at $-10^{\circ}$ until required, whereupon the samples were thawed and any further precipitate was again removed by centrifugation. When necessary, samples were diluted with basal salts solution (growth medium minus a carbon source) previously treated to remove phosphate in the same way as the samples.

Measurement of carbon dioxide and oxygen. Carbon dioxide was measured using an MSA infrared analyser, Lira Model 300 (Mine Safety Appliances Co. Ltd, Glasgow) and oxygen using a Servomex oxygen analyesr, type OAI84 (Servomex Controls Ltd, Crowborough, Sussex) according to the methods described by Hamilton \& Holms (I970).

\section{MATERIALS}

2-Amino-2-hydroxymethylpropane-1,3-diol, D, L-isocitric acid (trisodium salt), nicotinamide adenine dinucleotide, reduced (disodium salt), nicotinamide adenine dinucleotide, oxaloacetic acid, glycylglycine, coenzyme A, thiamine pyrophosphate chloride, D, L-isocitric acid lactone (allo-free), adenosine triphosphate (disodium salt), glucose 
6-phosphate (disodium salt), pyruvic acid (sodium salt) and D-galactose were obtained from Sigma (London) Chemical Co. Ltd. Nicotinamide adenine dinucleotide phosphate (disodium salt), triethanolamine hydrochloride, phosphoenolpyruvic acid (potassium salt), pyruvate kinase, lactate dehydrogenase, myokinase and acetate kinase were obtained from The Boehringer Corporation (London) Ltd.

2-Oxoglutaric acid and malic acid were obtained from Fluka AG (Chemische Fabrik, CH-9470 Buchs, Schweiz). D-Mannitol was obtained from Thomas Kerfoot \& Co. Ltd (Vale of Bardsley, Lancashire). Potassium cyanide was obtained from Hopkin \& Williams Ltd (Chadwell Heath, Essex). Chloramphenicol was obtained from Parke, Davis \& Co. (Hounslow, London). Bovine plasma albumin (fraction V) was obtained from Armour Pharmaceutical Co. Ltd (Eastbourne, England). L-Cysteine hydrochloride monohydrate was obtained from T. J. Saz \& Son Ltd (Holborn, London). All other chemicals were of AnalaR quality from British Drug Houses Ltd (Poole, Dorset).

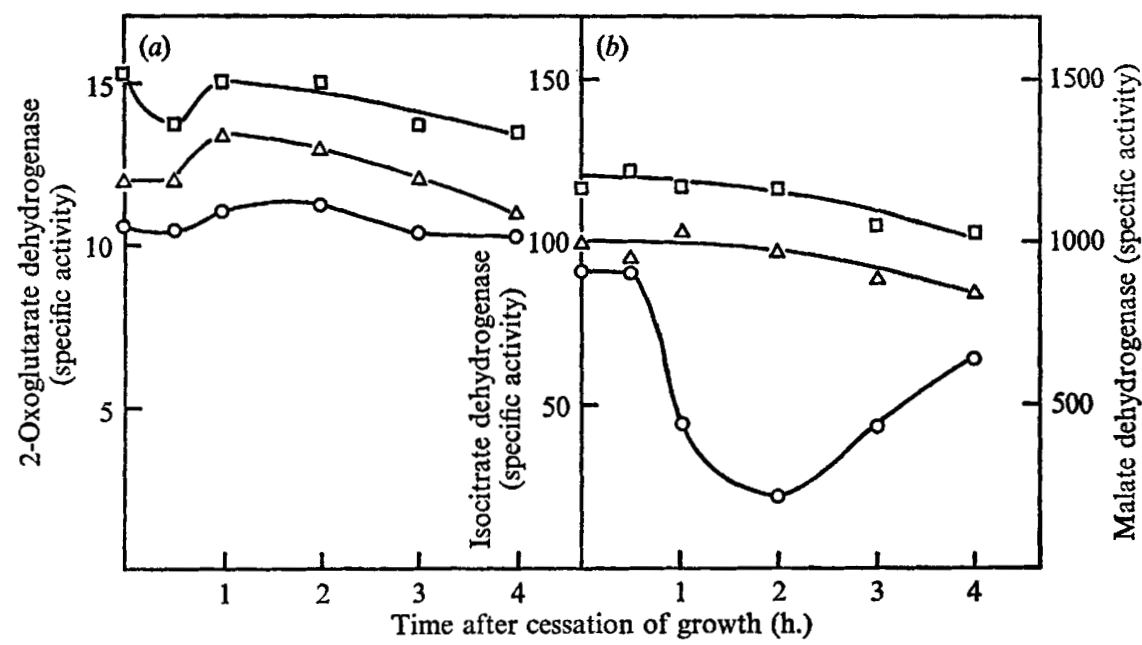

Fig. 2. Stability of isocitrate, 2-oxoglutarate and malate dehydrogenases after growth (a) on glycerol $(4 \mathrm{~mm})$ and $(b)$ on glucose $(2 \mathrm{mM})$. Organisms were periodically harvested by centrifugation (ro,000g at $4^{\circ}$ for $10 \mathrm{~min}$.) during stationary phase and the resulting pellets were resuspended in ice-cold, glass distilled water to a measured turbidity $\left(E_{420 \mathrm{~mm}}\right)$ of approximately $8 \cdot 0$. A portion of this suspension was diluted I in 2 with ice-cold $0 \cdot I \mathrm{M}$-tris buffer, $\mathrm{pH} 7 \cdot 5$, and $3 \mathrm{ml}$. were subjected to ultrasonic disruption. The crude cell extract was assayed for malate dehydrogenase and 2-oxoglutarate dehydrogenase activities. A second portion of the water resuspension was diluted $\mathrm{I}$ in 2 with ice-cold, glass distilled water and further diluted $\mathrm{I}$ in 2 with ice-cold $0.3 \mathrm{M}-\mathrm{NaCl}$ containing bovine plasma albumin (IO mg.) $\mathrm{ml}$.). Three $\mathrm{ml}$. were subjected to ultrasonic disruption and the crude extract was assayed for isocitrate dehydrogenase activity. $\square$, Malate dehydrogenase; $\triangle, 2$-oxoglutarate dehydrogenase; $O$, isocitrate dehydrogenase. Specific activities $\equiv$ units enzyme/unit of turbidity $\left(E_{420 \mathrm{~nm}}\right)$

\section{RESULTS}

Stability of tricarboxylic acid cycle enzymes after limited growth

The activities of malate dehydrogenase, 2-oxoglutarate dehydrogenase and isocitrate dehydrogenase were maintained throughout a $4 \mathrm{~h}$. period following the cessation of growth on limiting glycerol (Fig. $2 a$ ), as were the activities of the first two enzymes 
throughout a similar period following growth on limiting glucose (Fig. $2 b$ ). However, shortly after the cessation of growth on glucose the activity of isocitrate dehydrogenase fell, and after $2 \mathrm{~h}$. in stationary phase $80 \%$ of the original activity had been lost. During the following $2 \mathrm{~h}$. enzyme activity rose again, and $4 \mathrm{~h}$. after growth ceased isocitrate dehydrogenase activity was restored to $75 \%$ of the maximum value.

\section{Oxygen consumption and carbon dioxide production during and after growth}

The difference in behaviour of isocitrate dehydrogenase after growth on limiting glycerol and glucose prompted us to examine the metabolic activity of organisms during and after growth on these two carbon sources. During growth on either compound, oxygen consumption and carbon dioxide production increased logarithmically (Fig. 3a,b). Once growth on glycerol ceased, oxygen consumption and carbon dioxide production fell rapidly to very low levels. After growth on glucose, both oxygen consumption and carbon dioxide production fell but subsequently both rose again and continued to do so for $\mathrm{I} \frac{1}{2}$ to $2 \mathrm{~h}$. Oxygen consumption and carbon dioxide production rapidly fell to very low levels $2 \frac{1}{2}$ to $3 \mathrm{~h}$. after growth ceased.

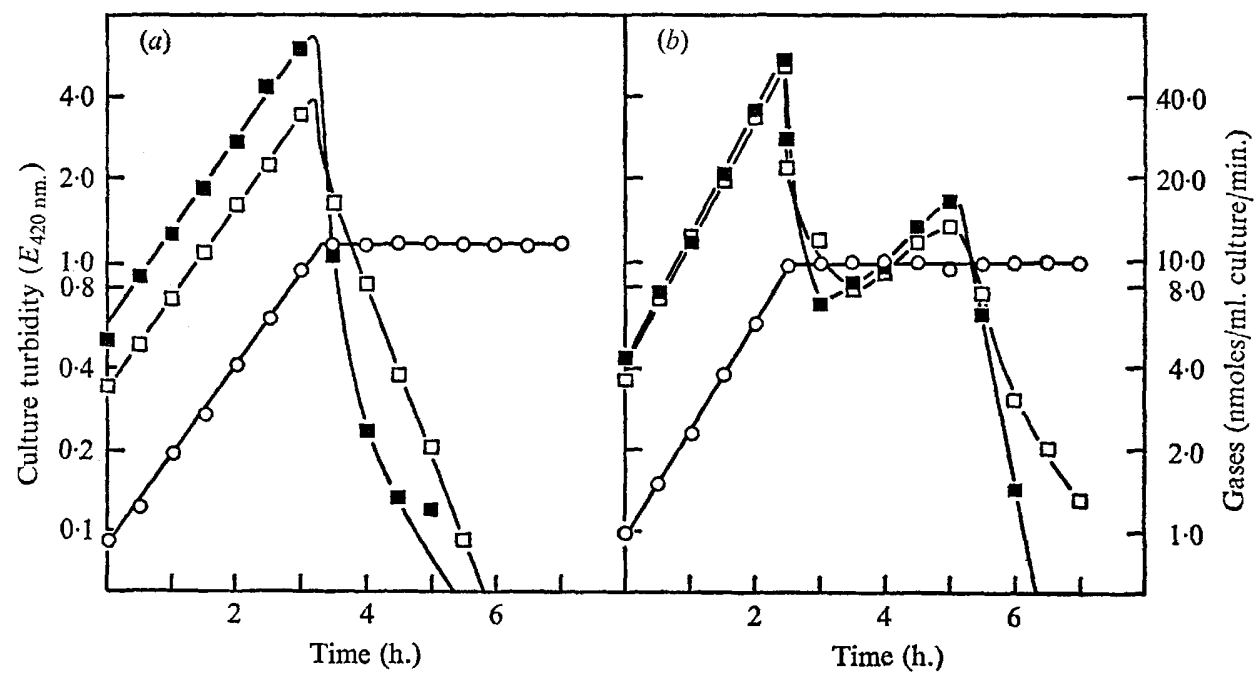

Fig. 3. Oxygen consumption and carbon dioxide production during and after growth: (a) on glycerol (4 mM); (b) on glucose ( $2 \mathrm{mM})$. $\mathbf{a}$, Oxygen consumption; $\square$, carbon dioxide production; $O$, culture turbidity.

\section{Acetate production during growth on limiting glucose}

Britten (1954) observed that acetate accumulated in the medium of well aerated cultures of Escherichia coli growing on glucose, and Hadjipetrou, Gerrits, Teulings \& Stouthamer (1964) observed a similar result for Aerobacter aerogenes. These latter workers also showed that, following glucose exhaustion, oxidation of the accumulated acetate then occurred.

Fig. $4^{b}$ shows that, during growth, glucose disappeared from the medium and acetate accumulated. Growth ceased upon glucose exhaustion, and utilization of the accumulated acetate began. While acetate was being used, isocitrate lyase activity greatly increased while that of isocitrate dehydrogenase fell (Fig. 4a). When acetate 
was exhausted, no further increase in isocitrate lyase activity occurred and isocitrate dehydrogenase activity largely recovered. We failed to detect any accumulation of acetate during growth on a limiting concentration of glycerol and no increase in isocitrate lyase activity was observed once growth ceased.

The addition of chloramphenicol at the end of growth on limiting glucose prevented the increase in isocitrate lyase activity (Fig. $4 a$ ) and markedly slowed, but did not stop, utilization of the accumulated acetate (Fig. $4 b$ ). The addition of this compound, however, prevented loss of isocitrate dehydrogenase activity (Fig. $4 a$ ).

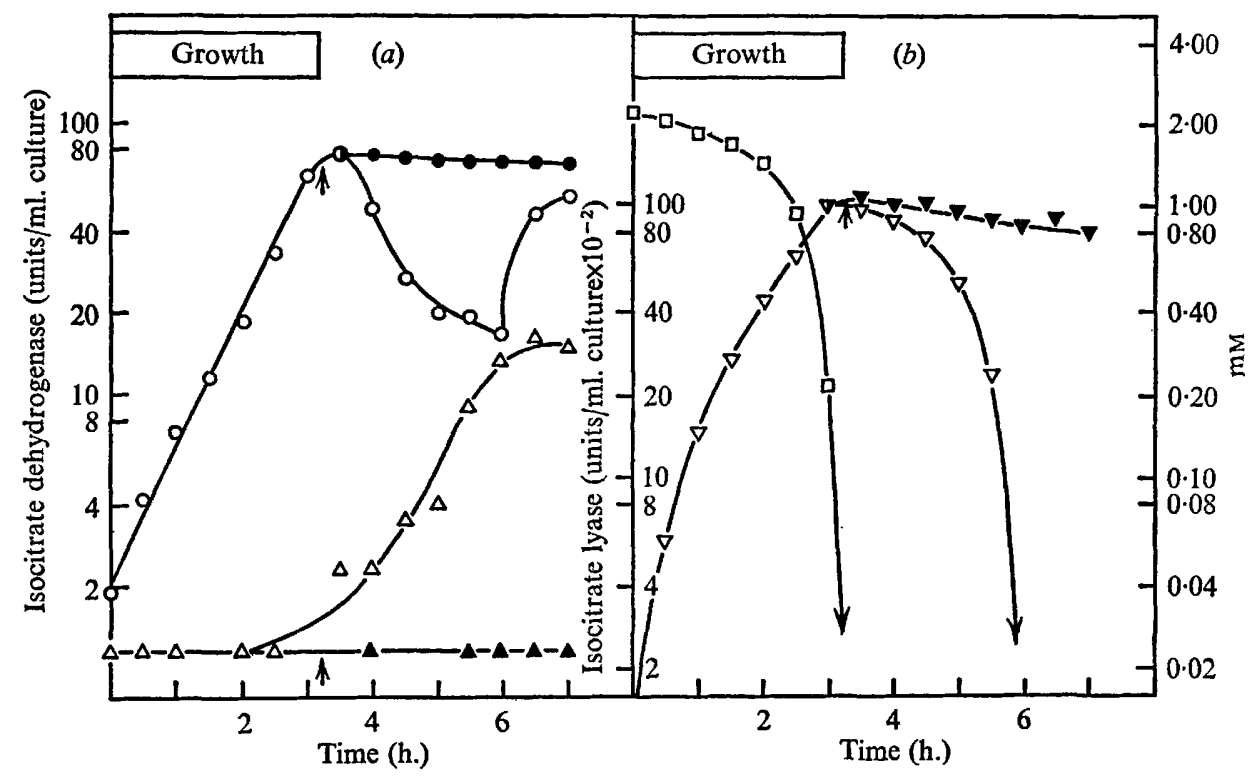

Fig. 4. Isocitrate dehydrogenase, isocitrate lyase, glucose and acetate levels during and after growth on glucose $(2 \mathrm{mM})$ and the effect of chloramphenicol added after the end of growth. (a) $\bigcirc$, Isocitrate dehydrogenase; $\triangle$, isocitrate lyase; no chloramphenicol added. $\bullet$, Isocitrate dehydrogenase; $\Lambda$, isocitrate lyase; after chloramphenicol $(0.3 \mathrm{~mm})$ added to culture $(\uparrow)$. (b) $\square$, Glucose; $\nabla$, acetate; no chloramphenicol added. $\nabla$, Acetate; after chloramphenicol $(0.3 \mathrm{~mm})$ added to culture $(\uparrow)$.

The growth bars, in this and following figures, indicate the period during which growth occurred.

\section{Effect of addition of acetate after limited growth on various sources of carbon}

The results presented above related loss of isocitrate dehydrogenase activity to utilization of acetate. When acetate (I mM) was added after growth on limiting glycerol, the activity of isocitrate dehydrogenase fell and then partially recovered (Fig. 5). Simultaneous addition of chloramphenicol with the acetate completely prevented this loss.

The activity of isocitrate dehydrogenase decreased and subsequently recovered after growth on glucose 6-phosphate, mannitol and pyruvate. No loss occurred after growth on galactose, fructose, 2-oxoglutarate, succinate or malate, but addition of acetate (I mM) at the end of growth on all these compounds induced a loss of isocitrate dehydrogenase activity, which was again followed by a partial recovery of enzyme activity. 


\section{Prevention of loss of isocitrate dehydrogenase activity}

When further glucose ( $2 \mathrm{mM}$ ) was added at the end of growth on glucose ( $2 \mathrm{mM})$, growth resumed and no loss of isocitrate dehydrogenase activity occurred. When growth ceased a second time, loss of enzyme activity, followed by a partial recovery, was then observed. Addition of pyruvate ( $\mathrm{I} \mathrm{mm}$ ) after the first period of growth on glucose $(2 \mathrm{mM})$ produced a similar result, growth being resumed for a short period without loss of enzyme activity. However, upon cessation of this second phase of growth, enzyme activity fell and then, subsequently, was partially restored.

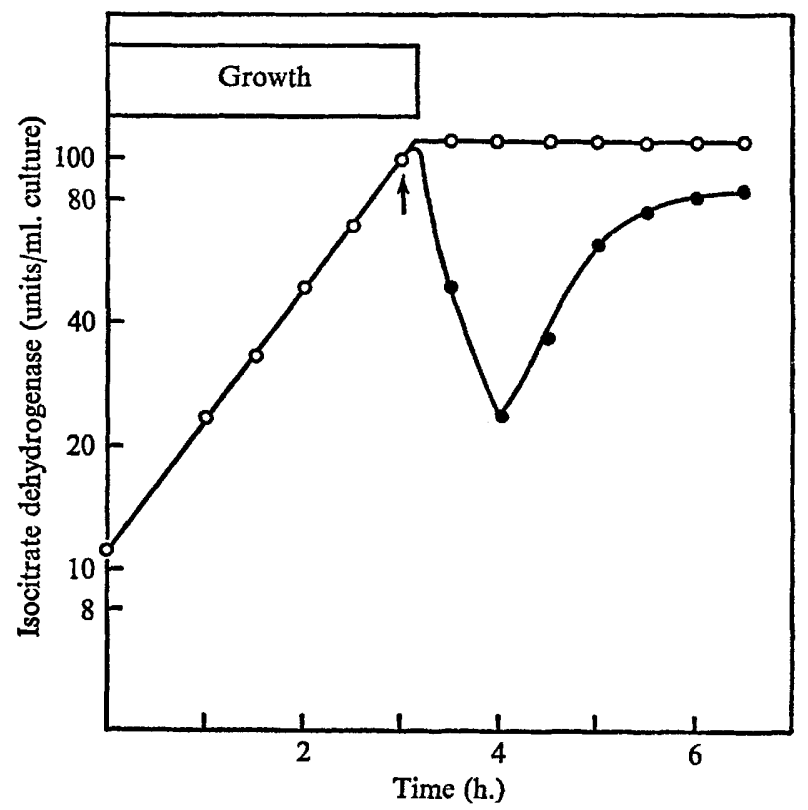

Fig. 5. Isocitrate dehydrogenase activity after addition of acetate (I $\mathrm{mM}$ ) at the end of growth on glycerol $(4 \mathrm{~mm})$. $\bigcirc$, Isocitrate dehydrogenase, no acetate added; $\bullet$, isocitrate dehydrogenase, after addition of acetate $(\uparrow)$.

Addition of malate ( $\mathrm{mm}$ ), after the cessation of growth on glucose, caused a resumption of growth. When growth again stopped, no loss of isocitrate dehydrogenase activity followed (Fig. 6). Similar results were obtained when succinate, fumarate or oxaloacetate (all at $\mathrm{I} \mathrm{mM}$ ) were added in place of malate. On the other hand, isocitrate dehydrogenase activity declined even after addition of 2-oxoglutarate (I mM) at the end of growth on limiting glucose, although recovery of activity was hastened.

When these experiments were repeated using cultures grown on glycerol, and when succinate (I mM), fumarate (I mM), malate (I mM), oxaloacetate (I mM), 2-oxoglutarate (I mM) or pyruvate (I mM) were added simultaneously with acetate (I mM), similar results were obtained. The addition of the tricarboxylic acid cycle intermediates separately, at the end of growth on glycerol, did not induce loss of isocitrate dehydrogenase activity. 


\section{Result of acetate utilization}

Fig. $4 a$ indicates that following growth on glucose, adaptation to acetate occurs. When sufficient acetate $(6 \mathrm{~mm})$ to permit measurable growth was added to cultures $2 \frac{1}{2} \mathrm{~h}$. or more after growth on glucose ceased, growth resumed immediately; whereas when the addition was made between the end of growth and $2 \frac{1}{2} \mathrm{~h}$. into stationary phase growth resumed $2 \frac{1}{2} \mathrm{~h}$. after growth stopped. When a similar series of experiments was performed using glycerol-grown cultures, resumption of growth depended on the time at which acetate was added, and the longer the addition was delayed the longer was the lag before growth recommenced.

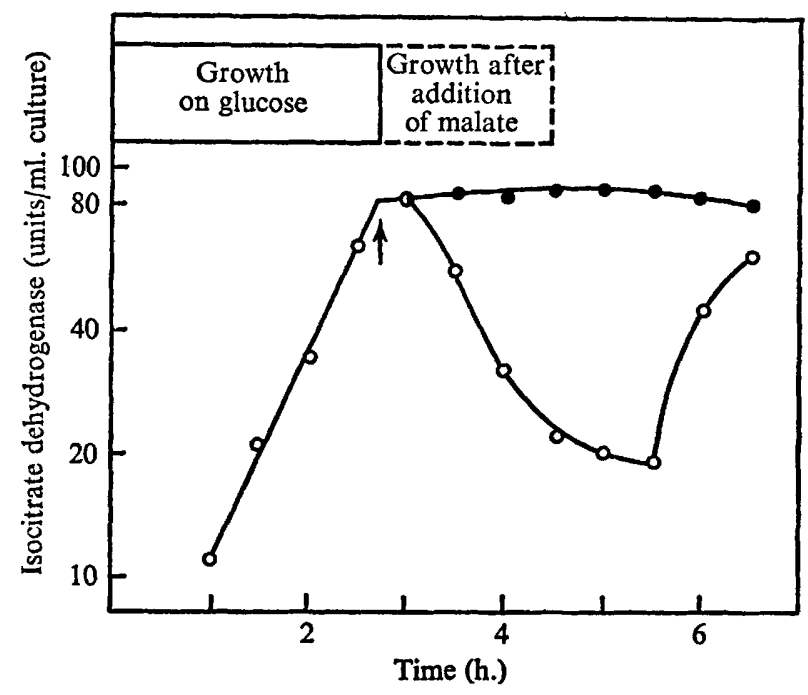

Fig. 6. Isocitrate dehydrogenase activity after the addition of malate (1 $\mathrm{mm}$ ) at the end of growth on glucose $(2 \mathrm{mM})$. $O$, Isocitrate dehydrogenase, no malate added; $\boldsymbol{O}$, isocitrate dehydrogenase, after addition of malate $(\uparrow)$.

\section{DISCUSSION}

During aerobic growth on limiting glucose approximately $17 \%$ of the glucosecarbon accumulates as acetate (Fig. $4 b$ ), a value which corresponds closely with the $15 \%$ accumulation of acetate reported by Roberts, Abelson, Cowie, Bolton \& Britten (1957) for another strain of Escherichia coli growing under similar conditions. When glucose is exhausted, the cells adapt to acetate; this results in the derepression of isocitrate lyase synthesis (Fig. $4 a$ ), an enzyme essential for growth on acetate (Ashworth \& Kornberg, 1964). Metabolic activity then recovers (Fig. $3 b$ ) and acetate is consumed (Fig. $4 b$ ). While acetate is utilized, isocitrate dehydrogenase activity falls to approximately $25 \%$ of its original level (Figs $2 b, 4 a$ ) but malate dehydrogenase and 2-oxoglutarate dehydrogenase activities remain virtually unaltered. Once the acetate is exhausted, isocitrate dehydrogenase activity is restored to about $75 \%$ of its original level.

The loss of isocitrate dehydrogenase activity depends on acetate. Growth on carbon sources, such as glycerol, the metabolism of which does not lead to acetate accumula- 
tion, is not followed by a decline in enzyme activity (Fig. $2 a$ ). However, if acetate is added to these cultures at the end of growth, a cycle of loss and recovery of enzyme activity is observed (Fig. 5), whereas addition of other intermediary metabolites invokes no such response. The effect obviously depends on a particular mode of acetate metabolism, since the addition of chloramphenicol, which inhibits synthesis of isocitrate lyase (Fig. $4 a$ ) and therefore adaptation to acetate, prevents loss of isocitrate dehydrogenase activity (Fig. 4a), although acetate metabolism continues (Fig. $4 b$ ). Also, the addition of a variety of compounds at the end of growth on glucose, or

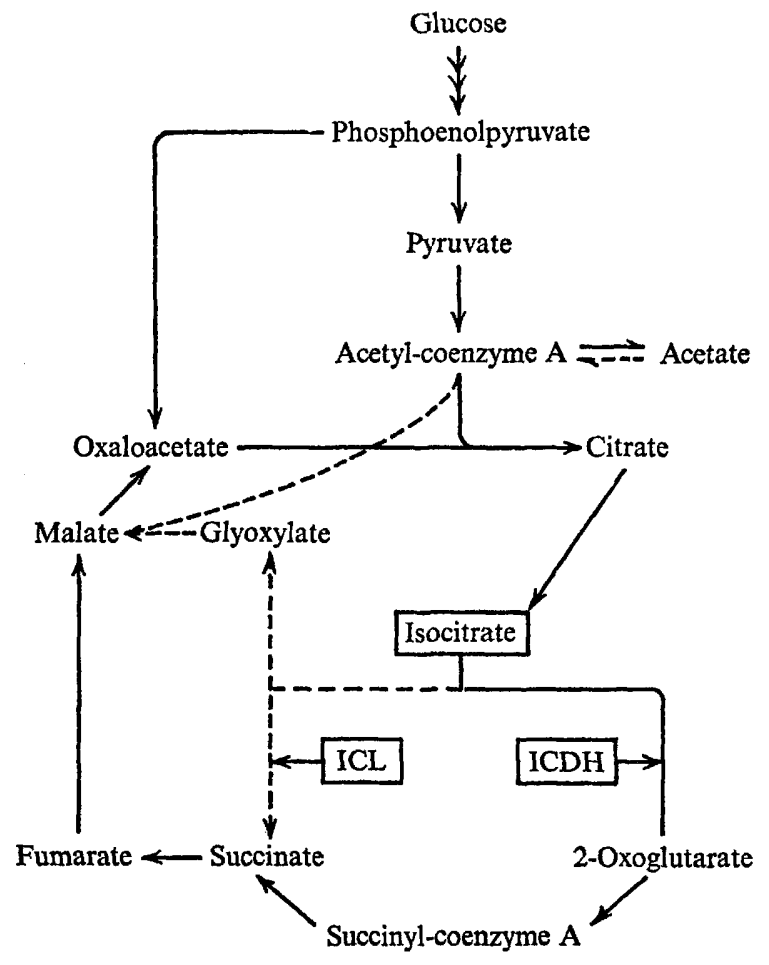

Fig. 7. Relationship between glucose and acetate metabolism. The broken-line arrows indicate metabolic reactions peculiar to acetate metabolism. ICL = isocitrate lyase; $\mathrm{ICDH}=$ isocitrate dehydrogenase.

simultaneously with acetate after growth on glycerol, totally prevents loss of enzyme activity (Fig. 6). This category includes those Krebs cycle intermediates which can be readily metabolized, the addition of which makes the glyoxylate bypass redundant. Kornberg, Collins \& Bigley (1960) reported that addition of succinate to cultures of Micrococcus denitrificans, growing on actate, resulted in the repression of isocitrate lyase synthesis, while we have observed that isocitrate lyase synthesis in Escherichia coli ML 308 is repressed when either succinate or malate is added to cultures growing on acetate (P. M. Bennett, unpublished results). Therefore, during conditions when derepression of synthesis of isocitrate lyase does not occur, no loss of isocitrate dehydrogenase activity is observed, although acetate metabolism may continue. Apparently, therefore, the loss of enzyme activity is peculiar to cells committed to acetate as sole 
source of carbon and energy. The effect is specific to isocitrate dehydrogenase, in that the activities of two other key enzymes of the tricarboxylic acid cycle remain unaffected (Fig. $2 b$ ).

Also peculiar to utilization of acetate as sole source of carbon and energy is the cell's demand for the anaplerotic pathway known as the glyoxylate bypass (Kornberg, 1966). It is significant that loss of isocitrate dehydrogenase activity follows the derepression of synthesis of isocitrate lyase (Fig. 4a), the first enzyme of the glyoxylate bypass, and it is equally striking that recovery of enzyme activity corresponds with the cessation of glyoxylate bypass action, when acetate is exhausted (Fig. $4 a, b$ ).

As shown in Fig. 7, the glyoxylate bypass and isocitrate dehydrogenase compete for their common substrate, isocitrate. We suggest that this competition is resolved in favour of the glyoxylate bypass, by inactivation of isocitrate dehydrogenase. This occurs when acetate is sole source of carbon and energy. Enzyme activity is restored upon acetate exhaustion. Enzyme activity can be maintained in the presence of acetate, provided that an alternative source of the products of the glyoxylate bypass is available, when 'bypass' activity becomes redundant. The whole effect is seen as a mechanism which permits isocitrate to be preferentially metabolized via the glyoxylate bypass when this is essential for maintenance of a balanced metabolism.

Thanks are due to the Medical Research Council for a Research Studentship awarded to P.M.B.

This work was supported in part by grants from the Science Research Council, Medical Research Council and the Royal Society.

\section{REFERENCES}

Ashworth, J. M. \& KorNBerG, H. L. (1964). The role of isocitrate lyase in Escherichia coli. Biochimica et biophysica acta 89, 383-384.

BenNeTT, P. M. \& Holms, W. H. (1969). Lability of isocitrate dehydrogenase in Escherichia coli. Journal of General Microbiology 58, iv.

Britten, R. J. (1954). Extracellular metabolic products of Escherichia coli during rapid growth. Science, New York 119, 578.

Dixon, G. H. \& Kornberg, H. L. (I959). Assay methods for key enyzmes of the glyoxylate cycle. Biochemical Journal 72, 3 P.

Gray, C. T., Wimpenny, J. W. T. \& Mossman, R. M. (I966). Regulation of metabolism in facultative bacteria. II. Effects of aerobiosis, anaerobiosis and nutrition on the formation of Krebs cycle enzymes in Escherichia coli. Biochimica et biophysica acta 117, 33-41.

Hadipetrou, L. P., Gerrits, J. P., Teulings, F. A. G. \& Stouthamer, A. H. (1964). Relation between energy production and growth of Aerobacter aerogenes. Journal of General Microbiology 36, 139-150.

Hamilton, I. D. \& Holms, W. H. (1970). Measurement of respiration of micro-organisms during batch culture. Laboratory Practice 19, 795-798.

Harvey, N. L., Fewson, C. A. \& Holms, W. H. (1968). Apparatus for batch culture of microorganisms. Laboratory Practice 17, I I34-I I 36.

KoRNBERG, H. L. (I966). The role and control of the glyoxylate cycle in Escherichia coli. Biochemical Journal 99, I-I I.

Kornberg, H. L., Colirns, J. F. \& Bigley, D. (1960). The influence of growth substrates on metabolic pathways in Micrococcus denitrificans. Biochimica et biophysica acta 39, 9-24.

Mehler, A. H., Kornberg, A., GrisoliA, S. \& OChOA, S. (1948). The enzymatic mechanism of oxidation reductions between malate or isocitrate and pyruvate. Journal of Biological Chemistry 174, $96 \mathrm{I}-977$. 
MukherJee, N. B., MATthews, J., HoRney, D. L. \& Reed, L. J. (1965). Resolution and reconstitution of the Escherichia coli $\alpha$-ketoglutarate dehydrogenase complex. Journal of Biological Chemistry 240, PC 2268-2269.

Roberts, R. B., Abelson, P. H., Cowie, D. B., Bolton, E. T. \& BRitten, R. J. (1957). Extracellular products of metabolism. In Studies of Biosynthesis in Escherichia coli, pp. 184-206. Washington, D.C.: Carnegie Institution of Washington Publication 607.

SLeIN, M. W. (1963). D-Glucose. Determination with hexokinase and glucose 6-phosphate dehydrogenase. In Methods of Enzymatic Analysis, pp. I 17-1 23. Edited by H. U. Bergmeyer. Weinheim an der Bergstr: Verlag Chemie, GMBH; and New York and London: Academic Press. 